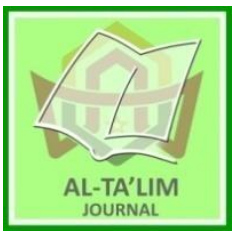

AL-TA'LIM JOURNAL, 26 (2), 2019, (131-146)

(Print ISSN 1410-7546 Online ISSN 2355-7893)

Available online at http://journal.tarbiyahiainib.ac.id/index.php/attalim

\title{
Translating from English into Indonesian: Which techniques to teach EFL students to be professional translators?
}

Received: $14^{\text {th }}$ October 2018; Revised: $6^{\text {th }}$ July 2019 ; Accepted: $30^{\text {th }}$ July 2019

Permalink/DOI: http://dx.doi.org/10.15548/jt.v26i2.521

Faisal Mustafa*)

Universitas Syiah Kuala, Banda Aceh, Indonesia

E-mail: faisal.mustafa@unsyiah.ac.id

\section{Mohammad Kholid}

Monash University, Melbourne

Australia

E-mail: kholidmohammad@ymail.com

*) Corresponding Author

\begin{abstract}
The credits for translation courses offered at the study program of English Language Teaching at a university level in Indonesia are very limited, which is not sufficient to teach and facilitate practices for all techniques of translation. Therefore, the students should only be taught techniques frequently used in translation from English to Indonesian. This research was to analyze translation techniques commonly used in translating from English to Indonesian. The data were collected from Colors magazine, an in-flight magazine for Garuda Indonesia. The magazine comes in two languages. The sentences were extracted, and translated sentences in Indonesian were compared to the original version in English. The research results showed that the most frequently used techniques in translating from English into Indonesian are amplification (23.36\%), reduction (15.20\%), transposition (12.32\%), borrowing (12\%), modulation (11.68\%), and literal translation (10.08\%). Therefore, it is recommended that lecturers teaching students majoring English Language Teaching provide them with those techniques of translations with practices, feedbacks and explicit instruction for revisions.
\end{abstract}

Keywords: Translation technique; English to Indonesian; teaching translation; EFL students.

How to Cite: Mustafa, F., \& Kholid, M. (2019). Translating from English into Indonesian: Which techniques to teach EFL students preparing to be professional translators?.Al-Ta Lim Journal, 26(2). doi:http://dx.doi.org/10.15548/jt.v26i2.521

\section{INTRODUCTION}

Universities in Indonesia provide two majors for graduates of high school who are interested in learning English at advanced level. However, there is no pure EFL study program offered in Indonesia. Students are to choose between English Literature and English Language Teaching. In Indonesia, English Language Teaching is the most popular study program for high school graduates who are interested in learning English because it is offered by many universities. However, job vacancies available for school teachers after they graduate are not abundant, nor are all of the graduates interested in being English teachers. This would have created more unemployed graduate if the university did not offer elective courses which provide graduates with more entrepreneur skills. Among those elective causes is translation. This course is essential because a translator is very employable in this globalization era, and the translators working in governmental institutions are very few. For some of those reasons, Karimian \& Talebinejad (2013); Kim (2010); Ross (2000) considered translation as the fifth skill in language learning, in addition to listening, structure, reading, speaking, and writing. However, syllabi designed for this 
course by most English Language Teaching programs in Indonesia are not intended to prepare the students to be translators. The course teaches students the theory of translation, which includes the history of translation, different definitions proposed by translation experts, and other non-practical knowledge. It seems that techniques of translation are not the main focus of this course, although some universities do address them in brief. Zainudin \& Awal, (2012a, $2012 b$ ) have suggested that mastering translation techniques is the key to being a competent translator, which is also supported by (Coban, 2015). However, universities are usually only able to provide 2 hours a week for translation course, making it very challenging to teach all translation techniques, like those listed by (Molina \& Hurtado Albir, 2002). Therefore, only translation techniques frequently used to translate from English into Indonesian should be taught to students in very detail and comprehensive. The current practice shows that from four translation syllabi available online for the public, only two of them include techniques of translation; however, one provides only two techniques, and the other offers six but all are taught in 2 meetings. It is somewhat motivated by the absence of research on which techniques are frequently used in translating from English into Indonesian. Therefore, this research is aimed at finding out those techniques. The results of this research will benefit universities offering translation courses at their English Language Teaching program.

\section{Translation module in Indonesian EFL programs}

Designing a curriculum requires a deliberate process. One of which is the need analysis Richards (2001) to find the purpose of learning. For EFL programs in Indonesia, the purpose is to prepare school teachers to teach English. In addition, students are also prepared for other professions, such as translators. Therefore, every EFL program in Indonesian universities offers one or more translation courses. As in other countries, as claimed by Dam \& Koskinen, (2016);
Gouadec (2007), many translation instructors do not have a qualification to teach translation in Indonesia, but they were language teachers assigned to teach translation because they were once translators. Because they learned translation autodidactic through practices, they apply the same principle in translation class, i.e. practice-based activities, which is considered as "traditional pedagogy of translation" Petrescu (2015), without expertrecommended techniques or accompanying theoretical guidelines, which (Prieto Ramos, 2011; Schäffner \& Adab, 2000) insisted that it is significant. A similar teaching method was also reported in China (Yang, Li, \& Xing, 2018). Some incorporate non-applicable theories, which are more likely to trouble students because relating theories into practice has been proven challenging (Gouadec, 2007). Therefore, to achieve the purpose of the translation module to be professional translators, students are to teach techniques of translation applicable to translate from English into Indonesian. The following section lists techniques of translation which are not language specific, later in this paper showed techniques to be used in translating from English into Indonesian.

\section{Techniques of translation}

Translators must pay a lot of attention to the quality of translation. It requires them to have natural insight and knowledge as well as the cultural variations of source and target languages in order that the readers are unaware that it is a translated version. To achieve the best quality of translation, translators should integrate their core competencies in translation with the appropriate translation techniques, sometimes referred to as method or procedure. It is defined by Désilets, Melançon, Patenaude, \& Brunette (2009) as the strategies used by translators as "translator's potentially conscious plans for solving concrete translation problems in the framework of a concrete translation task". There are 18 techniques proposed by (Molina \& Albir, 2002). Robinson (2012); Shuttleworth (2014); 
Venuti (2012) also proposed somewhat similar ideas, but less detail. The following are techniques of translation adapted from those experts.

\section{Literal Translation}

A literal translation is a technique of translating word-for-word from SL to TL without necessarily preserving the TL word order rule Khodadady \& Lagzian (2013), although some "'syntactic structure of the source text is painfully evident in the translation" (Robinson, 2012). It tries to remain as close to the original text as possible, without adding any thoughts from the translator in the translation (Millán \& Bartrina, 2013). Unlike the word-for-word translation technique, literal translation connects the grammatical rules between the source language and the target language. However, literal translators are very often viewed as 'being ignorant of cultural differences (Robinson, 2012). In fact, Etienne Dolet, a pioneer of translation theories living in the 16th century, had suggested not to use a literal translation technique (Farghal \& Ali Almanna, 2015). With the development of translation theories, now it has brought to light that literal translation is sometimes possible, especially when two languages involved are from the same language family (Bowker, 2001).

\section{Calque}

Calque is another name for throughtranslation. It refers to a translation technique which transfers words or phrases from SL into TL either lexically or structurally. It is only advisable when the TL does not have the equivalence of the SL (Pym, 2014). This problem is very common in translating legal texts (Stepanova, 2017). For example, secretariat general is translated into sekretaris jendral. Structural interference of the source language is the identity of calque translation technique. This technique is commonly used in translating "common collocations, names of organizations, the components of compounds ... and perhaps phrases".

\section{Borrowing}

Borrowing technique is either characterized as pure borrowing or naturalized borrowing. This technique is also known as 'transference" by Chesterman (2011), while Schaeffer \& Carl (2014) called it 'loan word". New technologies which rapidly enter the surrounding reality and create many words unavailable in other languages are the reason why borrowing technique is prominent. For example, hard disk is translated into hard disk. Stroilova \& Makarova (2016)__also found that this technique was used in translating poems, and in translating puns by Perez (2014). Lambert \& Van Gorp (2014) suggested to take the word in the source language to be adjusted with the sound or pronunciation in the target language; such as computer in English becomes komputer / komputər/ in Indonesian, and goal becomes $\mathrm{gol} / \mathrm{gol} /$.

\section{Established equivalence}

Some words or phrases, or even sentences in SL have translated versions which are commonly used in the TL. For most English terms and words, the suggested equivalence in Indonesian has been written by National Center for Language Development (Suryawinata \& Hariyanto, 2003). This technique of translation is termed as established equivalence technique (Molina \& Albir, 2002), and also known as 'recognized translation" or 'accepted standard translation" Lewis, Rosenkrantz, \& Stearns (2009) suggested using this technique in translating "onomatopoeia of animal sounds, ... idioms, clichés, proverbs, nominal or adjectival phrases."

\section{Generalization}

In certain languages, some words are not divided into more specific senses. Snow in English, for example, does not have many specific terms as snow in Eskimo, although 
there are some disagreements regarding these differences. Therefore, in Eskimo the word qanisqineq literally meaning "caked-up snow on the water" Jacobson (2012) can be translated into only snow in English. This technique of translation is referred to as "generalization" (Molina \& Albir (2002), and "less expressive" equivalence. This technique is very commonly used when translating cultural words which will sound less natural if translated literally. In Indonesian, the word becak" a three-wheeled passenger vehicle where the driver paddles it either behind or on the right side of the passenger" can be translated into vehicle in English.

\section{Particularization}

Contrast to generalization, particularization is a technique where a translator chooses the equivalence for a general term in SL into a specific term in TL (Molina \& Albir, 2002). This technique is used when only a specific term is lexicalized in TL, while the meaning of the word in the $\mathrm{SL}$ is more extended. Indonesian word for "farmer" is petani; however, it is only used to refer to farmers working in the field producing crops. Therefore, by using particularization technique the word "farmer" whose meaning in English extends to people raising field orchards, vineyards, poultry, or other livestock can be translated into petani, whose meaning is narrower, in Indonesian.

\section{Description}

When a word from SL does not have an equivalence in TL, such as what Serpil (2016) in English-German translation, the word can be described, instead of translating it, known as description technique Molina \& Albir (2002), which is also recommended in translating culture-specific item (Horbačauskienè, Kasperavičiene, \& Petronienè, 2016). Some words do not have equivalence in another language although the concept of the words is easily understood. Arabic, for example, does not have equivalence for the word standard (Baker, 1992, p. 21), as English does not have samurai, and thus has to be translated into "the Japanese aristocracy from the eleventh to the nineteenth century". In Indonesian, there is ketupat which has to be described as "rice cake eaten during Eid".

\section{Amplification}

Some words in SL do have equivalences in TL, but some of them cannot express the sense of SL, such as an example given by Muniz, Hambleton, \& Xing (2001) that hujan-hujanan in Indonesian simply means "going out in the rain" but it is with knowledge that it is raining. Therefore, some words have to be added to accommodate this sense, e.g. "going out in spite of the rain" which suggests that raining is not without knowledge. Amplification is also used when a less familiar word in TL needs to be explained, such as رَمَضَان/raməza'n/ translated and amplified into "Ramadhan, the Muslim month of fasting" (the example taken from Molina and Albrir (2002). When the amplifying phrase or clause is too long to be included in the text, he suggested adding a footnote either at the bottom of the page or the end of the translation works.

\section{Reduction}

Particularly in a poorly written text, when the translated version is so lengthily that it can distract readers away from the focus of the text, Gambier (2016) suggested skipping those distracting words or phrases if they do not harm the meaning of the text. In another case, insisting on translating these words sacrifices naturalness. Arffman (2010) also suggested using reduction technique when the words or phrases in SL cannot be, or too difficult to be, translated or when a translator needs to match the translated version to a certain style. Meanwhile, something is lost in translation when a translator uses this technique, yet it is considered "legitimate" in good-quality translation (Pym, 2014). Rojo (2014) found that using this technique may result in a loss in emotional impact in the TL. In translating 
legal documents, however, reduction technique is not recommended because it will potentially motivate "miscarriages of justice" (Millán \& Bartrina, 2013).

\section{Compensation}

Omission takes something out the SL, and when this loss is undesirable, a translator may use compensation technique where what has been lost in one part is inserted into another part of the sentence or the following sentence or the sentence after that. The purpose of inserting a compensating part is to regain the effect which has been lost, without necessarily using the same omitted expression. Havey (2014) emphasized that as long as the lost effect is compensated, language feature employed to compensate are non-restricted.

\section{Adaptation}

When cultural differences exist between SL and TL, adaptation technique is likely to be applied. It is the technique of replacing a culturally-meaning part from the SL with what is acceptable and natural in TL culture (Molina \& Albir, 2002; Pym, 2014). With this technique, it is the situation which is equivalent between SL and TL, not the language. This technique is considered "the 'freest' form of translation". It is to produce a translation version which is more natural in TL and effortless to understand by TL readers. (Bernardini, Stewart, \& Zanettin, 2014) did not recommend this technique when a translator is working with text where "the historical events and situations just as they occurred" is significant, such as religious text.

\section{Discursive creation}

As the name suggests, using discursive creation technique a translator translates by temporarily leaving the context of the SL (Molina \& Albir, 2002). The translated version sounds less similar, sometimes even completely different from the SL. This technique is recommended by Chesterman
(2009) if the 'parallel' translated text can potentially create misunderstanding, makes no sense, or gives difficulty for "an average reader" to interpret it. An example of how this technique is applied in translating from Indonesian into English was provided by Arafanti and Asmarani (2014), adapted in the following.

Terletak tak jauh dari pasar seni dan Budaya Ngarsopuri, Pura Magkunegaran adalah kediayaman pangeran Magkunurogo yang dibangun pada abad ke 18 den- gan arsitektur khas jawa, Joglo.

Literally translated:

Situated far from art market and Ngarsopuri Culture, Pura Magkunegaran is Prince Mangkunegaran's house which was built in the eighteenth century with Javanese unique architecture, Joglo.

Translated using discursive creation technique:

As the palace of the junior line for the royal family, Mangkunegaran is a unique house designed with beautiful Javanese architecture, Joglo.

The first sentence is not in line with the idea in SL, and the second sentence is not correlated to the SL either. This fact shows that the discursive creation technique was employed in translating the above sentences.

\section{Transposition}

Transposition is the translation technique which changes grammatical category and plurality from the source language into the target language by preserving the idea expressed in SL. Gritsenko (2016) showed that this technique was extensively used in translating song lyrics. There are several situations which motivate a translator to utilize this technique. In some conditions, the transposition is obligatory when the grammatical equivalence 
between the SL and TL is not present, as in the following example.

It is $\frac{\text { raining again. }}{\text { verb }}$

Hujan turun lagi. noun

Back-translated literally: 'The rain is falling again'

In another condition, the transposition is optional but translating without changing the word class results in a language with unnatural style, and recommended that transposition technique still be used in this situation. The other condition using this technique is to replace "a lexical gap", as in the following example.

\section{Rakyat berdemonstrasi, kemudian pada} awal Januari 2007, peraturan itu dirubah. Literally translated:

The citizen protested, then the regulation was amended at the beginning of January 2007.

Translated using transposition:

The citizen had protested before the regulation was amended at the beginning of January 2007.

The last example showed that the action of protesting happened earlier than that of the amendment; therefore, grammatical structure, i.e. past perfect (had + past participle) is used to replace the gap.

\section{Modulation}

This technique was proposed to be used when a literal translation is not semantically possible in TL. Using this technique, a translator makes a change in point of view that allows him to express the same phenomenon in a different way (Molina \& Albir, 2002). In modulation, the translator is meant to achieve the language level in the target language similar to how the native speaker expresses a similar sense of the source language. It involves changes in lexical, not grammatical resources as in transposition (Munday, 2009). In translating "you are going to have a grandchild" into Indonesian, for example, a translator writes Anda akan menjadi seorang kakek, backtranslated into "you will be a grandfather".

\section{Linguistic amplification}

In amplification technique, a translator makes the TL clearer by adding some words or phrases, which is almost similar to linguistic amplification except that it is the grammatical element which is used to amplify (Molina \& Albir, 2002) or it is lexical items to amplify grammatical elements (Newmark, 1988, p. 91). This is necessary when the meaning of SL text is not clear if translated as it is in the TL. Usually, the translated version becomes longer than the version in the SL. In Indonesian, appositive, which is a phrase in English, is usually expressed in a clause, and translating English appositive requires the use of linguistic amplification.

The elephant, the largest living land animal, is native to Africa and southern Asia.

Gajah, yang merupakan binatang paling besar yang hidup di daratan, berasal dari Afrika dan Asia selatan.

Back-translated:

The elephant, which is the largest living animal, originated from Africa and southern Asia.

\section{Linguistic compression}

Another technique to use in translation is to "synthesize linguistic element" (Molina \& Albir, 2002). Longer SL sentences are shortened when long or complex linguistic elements in the SL are made simpler. This technique is employed when simple, or 'synthesized' version can deliver the same effect in the TL. It is much recommended in translating subtitle because the shorter it is on the screen the more efficient it is for the viewers (Munday, 2009; Zagot \& Vozdvizhensky, 2014). In the case of English, 
future perfect continuous such as The Mountain will be being climbed by a group of teenagers can be translated into the following shorter sentence in Indonesian.

\section{Anak-anak muda sedang mendaki gunung.}

Back-translated: 'Teenagers are climbing the mountain.'

Changing a passive sentence into an active sentence reduces the verb "be" and preposition "by" and whether the action has been completed and will take place is not significant in Indonesian because it can be understood from the context. Therefore, "will be being climed by" can be synthesized into sedang, the continuous tense marker.

\section{Substitution}

Intonation and nonverbal communication are not simple things to translate because they are very cultural. One gesture in a language might donate different meaning in other languages, and this "need to be taken into account" (Bratož \& Kocbek, 2013). Therefore, (Molina \& Albir, 2002) suggested applying substitution technique in translating these forms of communication, which is converting these intonation and nonverbal communication forms into linguistic elements or the other way around. Bowing body in Japanese is one of the best examples, as in the following sentence:

彼は微笑んで彼の体を頭を下げました /kare wa hohoende kare no karada/ o tama o sayje macita/

Literally translated:

'He smiled and bowed his body.' technique:

Translated by using substitution

'He smiled and respectfully mimicked/said thank you very much.'
The example above shows that the word 'respectedly' and 'thank you very much' have been substituted to replace the action of bowing.

\section{Variation}

This technique of translation is primarily used in translating subtitles for movies (Chiaro, 2009). It is applied when the translator needs to "change linguistic or paralinguistic elements (intonation, gestures) that affect aspects of language variation: changes of textual tone, style, social dialect, geographical dialect" (Molina \& Albir). A gesture, in this case, is not replaced by words as in substitution, but by another equivalent gesture. Translating 'bowing his body in Japanese' into 'putting his hand on his heart in Arabic is an example of translating by using variation technique, as illustrated in the following. Molina and Albir (2002) also recommended using this technique in translating children novels, where the tone is changed. Therefore, children stories in English with brave, independent tones are advised to be translated into kind, obedient tones in Indonesian.

\section{METHOD}

This section shows sources of data which includes where the data were obtained and how were they selected, along with the procedure of data analysis.

To obtain the data for this research, the authors extracted the 20-22 first sentences in each article, unless the article is shorter than 20 sentences, along with the translated version in Indonesian, from Colours magazine, the in-flight magazine for Garuda Indonesia Flight, which is the Indonesian state-owned flight company. The magazine was selected because it provides translation from English into Indonesian with a very natural tone. One would not realize that it is the translated version being read unless it is made known to them. The following table presents the themes of randomly selected articles. 
Table 1. Description of the Source Text for Data Collection

\begin{tabular}{|c|c|c|c|c|}
\hline No. & Article titles (themes) & Editions & Sentences & Tokens \\
\hline 1 & Light painting calligraphy & Feb. 2016 & 20 & 43 \\
\hline 2 & Venice celebration time & Feb. 2016 & 21 & 63 \\
\hline 3 & Shanghai Chinese New Year celebration & Feb. 2016 & 15 & 42 \\
\hline 4 & Guangzhou feast of the east & Jan. 2016 & 20 & 55 \\
\hline 5 & The city of Stockholm & Jan. 2016 & 22 & 61 \\
\hline 6 & Maumere: Heart of the cape of flowers & Jan. 2016 & 21 & 63 \\
\hline 7 & Bengkulu to Palembang: Sumatra coast to coast & Dec. 2015 & 20 & 59 \\
\hline 8 & Melbourne to Sydney: Coasting along & Dec. 2015 & 21 & 63 \\
\hline 9 & Palu to Gorontalo & Dec. 2015 & 20 & 57 \\
\hline 10 & Archipelago: Birding in paradise & Oct. 2015 & 20 & 61 \\
\hline 11 & Western Australia & Oct. 2015 & 21 & 58 \\
\hline
\end{tabular}

Table 1 above shows that there are 221 sentences extracted from 11 articles taken from four editions of Colour Magazine, resulting in 625 tokens.

\section{Data analysis}

Each translated sentence was analyzed by comparing to the SL in English to decide what techniques were used to translate the sentence. The analysis was based on the techniques of translation classified by Molina and Albir (2002) because their translation techniques are the combination of techniques proposed by experts such as (Lee \& Jang, 2010). In addition, their classification is very detailed, consisting of 18 techniques discussed in Literature Review. The results were calculated to find out the frequency of technique used in translating from English into Indonesian in Colours magazine, with the percentage formula. Afterward, the techniques of translation were put in four categories, presented in Table 2.

Table 2. Categorization for the Frequency of Translation Techniques

\begin{tabular}{lll}
\hline No. & Categories & Description \\
\hline 1 & Frequently & The technique was used more than $10 \%$ \\
2 & Sometimes & The technique was used between $1 \%$ and $9 \%$ \\
3 & Rarely & The technique was used but less than $1 \%$ \\
4 & Never & The technique was not used at all \\
\hline
\end{tabular}

The analysis results were displayed in the next section and the technique categorized into 'frequently' were discussed further in more detail.

\section{RESULT AND DISCUSSION}

The results of data analysis revealed that not all techniques of translation proposed by Molina and Albir (2002) were used in translating Garuda Indonesia in-flight magazines, considered to represent the nature of English to Indonesian translation. The frequency of the translation techniques used is presented in Table 3.

Table 3. Results of Data Collection and Analysis

\begin{tabular}{llll}
\hline No. & \multicolumn{1}{c}{ Techniques of translation } & Tokens & \multicolumn{1}{c}{ Frequency } \\
\hline 1 & Amplification & 146 & $23.36 \%$ \\
2 & Reduction & 95 & $15.20 \%$ \\
3 & Transposition & 77 & $12.32 \%$ \\
4 & Borrowing & 75 & $12.00 \%$ \\
5 & Modulation & 73 & $11.68 \%$
\end{tabular}




\begin{tabular}{llll} 
No. & \multicolumn{1}{c}{ Techniques of translation } & Tokens & Frequency \\
\hline 6 & Literal translation & 63 & $10.08 \%$ \\
7 & Calque & 29 & $4.64 \%$ \\
8 & Adaptation & 21 & $3.39 \%$ \\
9 & Linguistic amplification & 13 & $2.08 \%$ \\
10 & Compensation & 10 & $1.60 \%$ \\
11 & Description & 8 & $1.44 \%$ \\
12 & Particularization & 6 & $0.96 \%$ \\
13 & Variation & 5 & $0.80 \%$ \\
14 & Discursive creation & 1 & $0.16 \%$ \\
15 & Established equivalent & 1 & $0.16 \%$ \\
16 & Linguistic compression & 1 & $0.16 \%$ \\
17 & Generalization & 0 & $0.00 \%$ \\
18 & Substitution & 0 & $0.00 \%$ \\
\hline
\end{tabular}

Table 3 shows that only 6 out of 18 techniques were frequently used in translating from English into Indonesian. Other five were used only sometimes, and five more were very rare. The other two were never used at all.

The first most frequently used technique is amplification. It is used to make the translated version more explicit by adding some lexical items. This technique was found very frequently because English and Indonesian are two completely different languages. Therefore, words or phrases in English which have equivalence in Indonesian are often not equivalent in terms of sense; therefore, some words or phrases need to be added to accommodate this untranslated sense. The example extracted from Colours magazine below illustrates this lack of equivalence.

Carnevale was revived in 1979, admittedly in part to give the low tourist season a boost, but also as a showcase of living Venetian history and culture.

Carnevale coba dihidupkan kembali tahun 1979, sebagai (bagian) upaya untuk meningkatkan arus wisatawan saat musim sepi liburan, selain juga sebagai ajang pertunjukan sejarah dan budaya Venesia.

In Indonesian version above, 'in part' which means 'sebagai bagian' is not clear of what part is being referred to; therefore, the translator added the word upaya 'effort' to make the sentence more explicit. Other research investigating the technique used in translating from English into Indonesian also revealed that amplification technique was one of the most commonly used techniques in translating humor in one of Harry Potter novels (Yuliasri, 2014) and movie subtitle of Doraemon (Fitria, 2015). Therefore, based on the nature of TL and SL, it is not unexpected that the amplification technique is one of the appropriate techniques to use in English Indonesian translation.

The second most commonly used translation technique used in translating from English into Indonesian is a reduction technique. Unlike amplification technique which makes the translated version more explicit, reduction technique tries to compress the information contained in the source language into the target language. In translating from English into Indonesian, this technique is often used in the context where certain parts of the sentence in English are unnecessary to be translated because they might cause redundancy in Indonesian as they have been known from the context, or in the worst scenario cause confusion. The following example shows how a professional translator used this technique in translating for Colours magazine.

Farmland undulates, giant trees erupt, and the purple crags of the Stirling Ranges loom.

Anda akan melihat lahan-lahan pertanian, pohon-pohon raksasa ------, dan tebing ungu Stirling Ranges. 
In the English version, we notice that the word 'erupt' was left out. Its equivalence in Indonesian is meletus and is usually used to describe an eruption of a mountain, but here it intends to inform the reader how gigantic the trees are. However, the metaphor is considered odd and unknown in Indonesian, and thus the word was omitted. This technique was also known to be popularly used in translating commercial advertisement (Pratama, 2015), when naturalness is important.

The third is transposition technique. It changes the sentence structure in English to produce a better, more natural translation in Indonesian. It involves the progress of changing the active into passive sentences and vice versa as well as a shift in grammatical structures such as part of speech and plurality. The data analysis results show that this technique was used to translate words, phrases, and sentences in English which cannot be literally translated into the same grammatical structure into Indonesian. These are shown in the following text sample extracted from Colours magazine.

As for the locals, they're the Italians of China: talkative, sociable, volatile and with a love of good food.

Penduduk setempat, mereka bagaikan orang Italia-nya China: banyak bicara, suka bergaul, ekspresif dan menyukai makanan enak.

Two examples of unit shift can be observed in the example, i.e. 'talkative' and 'sociable' which are both adjectives. The equivalences in Indonesian are cerewet but with negative sense and ramah but less expressive. Therefore, the translator translated both adjectives into verbs, i.e. banyak bicara 'talk much' which is more neutral in Indonesian and suka bergaul 'like to socialize' which is more expressive and natural. A similar shift in a part of speech also occurred in the prepositional phrase 'with a love of good food', which is translated into more natural verb phrase menyukai makanan enak 'love delicious food'. Transposition technique is also very useful to achieve equivalence above the word, to make translated version more comprehensible such as in translating movie subtitles (Nisaa, 2011), the meaning of which readers do not have time to process.

Borrowing was found almost in similar frequency to transposition. There have been many words entering English vocabulary, since it is the current language of science and technology, and those words cannot be translated into Indonesian simply because of Indonesian does not their equivalence. The following extracted sentence from Colours magazine shows that borrowing technique is sometimes obligatory.

On my fifth try, lightning struck the sea just behind the calligraphy.

Pada percobaan saya yang kelima, petir menyambar laut tepat di belakang kaligrafi.

The above is the example of naturalized borrowing or modified loan words. The word calligraphy is modified into 'kaligrafi' in Indonesian. The word shows significant difference morphologically, but slight contrast phonologically. The use of borrowing technique in the example was motivated by the fact that Indonesian does not have the equivalence for 'calligraphy'. This high frequency of borrowing used in translating from English into Indonesian was also revealed by Setyanta (2013) in the translation of The Memoir of Sherlock Holmes by Conan Doyle, and Lady's Chatterley Lover by D. H. Lawrence, analyzed by Srikandi (2010).

Another technique commonly used in translating English text into Indonesian is modulation, which facilitates translation by using a different way of conveying messages. It shapes and remodels the words and sentences in such a way to acquire a more natural form of translation in Indonesian. These changes include point of view, focus, and cognitive category in accordance with the 
English version. Unlike transposition technique which deals with grammatical changes, modulation technique uses different phrases between English and Indonesian to express the same idea.

Today it is easy to imagine that there would be many people who would welcome a life of peaceful exile in Bengkulu.

Di masa kini, rasanya banyak orang yang tak akan keberatan menikmati damainya kehidupan dalam pengasingan di Bengkulu.

In Indonesian, the verb 'welcome' can literally be translated into menyambut which is different both in structural form and meaning from the phrase used by the translator above, i.e. tak akan keberatan menikmati 'will not object to enjoy' that suits the context of Indonesian version, and thus makes the translation more comprehensible, as well as extremely natural. There are also several previous researchers who found that modulation technique is a feature of translated texts in Indonesian, such as Khairanis (2013), and even from other languages such as Japanese by Octaviani, (2015).

The last commonly used translation technique found in this research is literal translation. It is, in fact, common in other language pairs because it is "the default translation" technique from which all translation starts Arffman (2012). In the case of English - Indonesian language pairs, about $10 \%$ was found among 625 tokens. One of those is presented in the following example.

This image was captured in Toronto, with incredible luck.

Gambar ini diambil di Toronto, dengan keberuntungan luar biasa.

When translated word for word:

This image was captured in Toronto with incredible luck.
Ini gambar diambil di Toronto dengan luar biasa keberuntungan.

The above example shows that the translated version is similar in forms and order to those in the source text, only word orders in phrases are repositioned according to the grammatical rule of Indonesian. For example, unlike English, an adjective in Indonesian is put after noun so the words luar biasa keberuntungan should be correctly repositioned into keberuntungan luar biasa. In previous works by others, literal translation technique was found to be very common. It was the first mostly used technique in translating Economic Concept of Ibn Taimiyah book (Anshori, 2010), and The Godfather novel (Kuncara, Nababan, \& Samiati, 2013). Therefore, it can be concluded that literal translation serves as the basis of all translation techniques in English - Indonesian translation, as well as all other language pairs.

\section{CONCLUSION AND RECOMMENDATION}

The purpose of this research was to find out the techniques recommended to use in translating from English into Indonesian. The results of data analysis showed that not all techniques proposed were used in English - Indonesian translations. The most common techniques revealed in this research were amplification, reduction, transposition, borrowing, modulation, and literal translation with the percentage of between $10 \%$ and $23 \%$. In the range of between $1 \%$ and $9 \%$ were calque, adaptation, linguistic amplification, compensation, and description, and in the least frequent category were particularization $(0.96 \%)$, variation $(0.80 \%)$, discursive creation $(0.16 \%)$, established equivalent $(0.16 \%)$ and linguistic compression $(0.16 \%)$. In addition, generalization $(0.00 \%)$, and substitution $(0.00 \%)$ have not been used in Colours magazine.

These results are significant for lecturers and university administrators, as well as syllabus designers in deciding what to 
teach in a translation course for EFL undergraduate students. It is necessary because in the study program of English Language teaching in most universities in Indonesia, only two to three credits are offered for translation. In order to decide what to teach the students, teachers should know the objective of this course, i.e. to prepare students to be professional translators. Therefore, the students do not expect to be bombarded with nonpractical theories or only practices without theories, which are very common in traditional translation teaching in Indonesia according to writers' experience as EFL undergraduate students, but with techniques of translation (Gile, 2009; Gouadec, 2007), and the results of this research serve as the results of need analysis, based on which the course content is developed (Richards, 2001). Therefore, there are only six primary techniques to be taught to EFL students, i.e. amplification, reduction, transposition, borrowing, modulation, and literal translation, in order that they are able to professionally translate documents from English into comprehensible and natural Indonesian. While learning those techniques, they are to be provided with adequate practices, as suggested by Khusu and Unlu (2015) with constructive feedbacks and suggestions for revisions as suggested by Frase (2000) and Guodoc (2007). Since only six translation techniques are taught, the course instructors will have plenty of time for those activities, starting from the most serious problems (Károly, 2012; Wongranu, 2017). Unfamiliarity with these practical translation techniques may result in faulty translation (Yousofi, 2014). In addition, language training is no less significant in determining the quality of translation, as revealed by Khany (2014). Finally, different text genres should also be considered, considering the translation of research articles have become popular, and it presents more challenges to translators (Peterlin, 2014).

\section{REFERENCES}

Anshori, S. (2010). Teknik, metode dan ideologi penerjemahan buku
"Economic Concepts of Ibn Taimiyah" ke dalam Bhs. Ind. \& dampaknya pada kualitas terjemahan [Techniques, methods, and ideology in the translation of "Economic Concepts of Ibn Taimiyah" into Indonesian].

Arafanti, M., \& Asmarani, R. (2014). The translation techniques used in the bilingual destination map "Peta Wisata Jawa Tengah" translated into "Central Java Tourist Map." (Undergraduate dissertation). Dian Nuswantoro University, Semarang, Indonesia.

Arffman, I. (2010). Equivalence of translations in international reading literacy studies. Scandinavian Journal of Educational Research, 54(1), 3759.

Arffman, I. (2012). Unwanted literal translation: An underdiscussed problem in international achievement studies. Education Research International, 2012, 1-13.

Baker, M. (1992). In other words: A coursebook on translation.

Bernardini, S., Stewart, D., \& Zanettin, F. (2014). Corpora in translator education: An introduction. In Corpora in translator education (pp. 518). Routledge.

Bowker, L. (2001). Towards a methodology for a corpus-based approach to translation evaluation. Meta: Journal Des Traducteurs/Meta: Translators' Journal, 46(2), 345-364.

Bratož, S., \& Kocbek, A. (2013). Resurrecting translation in SLT: A focus on young learners. In D. Tsagari \& G. Floros (Eds.), Translation in language teaching and assessment (pp. 135-154).

Chesterman, A. (2009). The name and nature of translator studies. HERMESJournal of Language and 
Communication in Business, (42), 1322.

Chiaro, D. (2009). Issues in audiovisual translation. In Jeremy Munday (Ed.), The Routledge Companion to Translation Studies (pp. 141-165). London: Routledge.

Coban, F. (2015). Analysis and training of the required abilities and skills in translation in the light of translation models and general theories of translation studies. Procedia-Social and Behavioral Sciences, 197, 707714.

Dam, H. V., \& Koskinen, K. (2016). The translation profession: Centres and peripheries. Special Issue OfThe Journal of Specialised Translation25. AccessedMarch, 7, 2017.

Désilets, A., Melançon, C., Patenaude, G., \& Brunette, L. (2009). How translators use tools and resources to resolve translation problems: An ethnographic study. MT Summit XII-Workshop: Beyond Translation Memories: New Tools for Translators MT.

Díaz-Pérez, F. J. (2014). Relevance Theory and translation: Translating puns in Spanish film titles into English. Journal of Pragmatics, 70, 108-129.

Farghal, M., \& Ali Almanna. (2015). Contextualizing translation theories: Aspects of Arabic-English interlingual communication. Newcastle upon Tyne: Cambridge Scholars Publishing.

Fitria, T. N. (2015). Translation technique of English to Indonesian subtitle in Doraemon "Stand by Me" movie. Muhammadiyah University of Surakarta.

Fraser, J. (2000). The broader view: How freelance translators define translation competence. In C. Schäffner \& B. Adab (Eds.), Developing translation competence (pp. 51-62). Amsterdam: John Benjamins Publishing.

Gambier, Y. (2016). Translations| Rapid and Radical Changes in Translation and Translation Studies. International Journal of Communication, 10, 20.

Gile, D. (2009). Basic concepts and models for interpreter and translator training. Amsterdam: John Benjamins Publishing.

Gouadec, D. (2007a). Translation as a Profession (Vol. 73). John Benjamins Publishing.

Gouadec, D. (2007b). Translation as a profession. Amsterdam: John Benjamins Publishing.

Gritsenko, E., \& Aleshinskaya, E. (2016). Translation of song lyrics as structurerelated expressive device. Procedia Social and Behavioral Sciences, 231, 165-172.

Harvey, K. (2014). A Descriptive Framework for Compensation. The Translator, 1(January 2015), 37-41.

Horbačauskienė, J., Kasperavičienè, R., \& Petronienè, S. (2016). Issues of culture specific item translation in subtitling. Procedia - Social and Behavioral Sciences, 231, 223-228.

Jacobson, S. A. (2012). Yup'ik Eskimo Dictionary (2nd ed., Vol. 1).

Karimian, Z., \& Talebinejad, M. R. (2013). Students' Use of Translation as a Learning Strategy in EFL Classroom. Journal of Language Teaching \& Research, 4(3).

Károly, A. (2012). Translation competence and translation performance: Lexical, syntactic and textual patterns in student translations of a specialized EU genre. English for Specific Purposes, 31(1), 36-46. https://doi.org/10.1016/j.esp.2011.05.0 05 
Khairanis, A. (2013). Analysis of techniques used in translating idioms from English to Indonesian as found in All American Girls novel. Vivid Journal of Language and Literature, 2(1), 113.

Khany, R. (2014). Translation students' knowledge of lexical cohesion patterns and their performance in the translation of English texts. Procedia Social and Behavioral Sciences, 98, 925-931.

https://doi.org/10.1016/j.sbspro.2014. 03.501

Khodadady, E., \& Lagzian, M. (2013). Textual analysis of an English dentistry textbook and its Persian translation: A schema-based approach. Journal of Studies in Social Sciences, 2(1).

Kim, E.-Y. (2010). Using translation exercises in the communicative EFL writing classroom. ELT Journal, 65(2), 154-160.

Kuncara, S. D., Nababan, M. R., \& Samiati, S. (2013). Analisis terjemahan tindak tutur direktif pada novel [Analysis in the translation of direct speech act used in the novel Godfather and its translated version in Indonesian]. TransLing Journal: Translation and Linguistics, 1(1), 1-20.

Kuşçu, S., \& Ünlü, S. (2015). Teaching translation: A suggested lesson plan on translation of advertising through the use of authentic materials. Procedia - Social and Behavioral Sciences, 199, 407-414. https://doi.org/10.1016/j.sbspro.2015. 07.526

Lambert, J., \& Van Gorp, H. (2014). On describing translations. The Manipulation of Literature, 42-53.

Lee, Y., \& Jang, J. (2010). Language translator having an automatic input/output interface and method of using same.

Lewis, P. M., Rosenkrantz, D. J., \& Stearns, R. E. (2009). Attributed translations. In Fundamental Problems in Computing (pp. 13-43). Springer.

Millán, C., \& Bartrina, F. (2013). The Routledge handbook of translation studies. In The Routledge Handbook of Translation Studies. London: Routledge.

Molina, L., \& Albir, A. H. (2002). Translation Techniques Revisited: A Dynamic and Functionalist Approach. Meta: Journal Des Traducteurs, 47(4), 498-512. https://doi.org/10.7202/008033ar

Molina, L., \& Hurtado Albir, A. (2002). Translation techniques revisited: A dynamic and functionalist approach. Meta: Journal Des Traducteurs/Meta: Translators' Journal, 47(4), 498-512.

Munday, J. (2009). The Routledge companion to translation studies. London: Routledge.

Muniz, J., Hambleton, R. K., \& Xing, D. (2001). Small sample studies to detect flaws in item translations. International Journal of Testing, 1(2), 115-135.

Newmark, P. (1988). A Textbook of Translation. New York: Prentice Hall.

Nisaa, R. K. (2011). Analisis teknik, metode, dan ideologi penerjemahan subtitle film Beckham Unwrapped dan dampaknya pada kulitas terjemahan [The analysis of techniques, methods, and ideology used in the translation of Beckham Unwrapped movie subtitle and their impact on the.

Octaviani, E. D. (2015). Prosedur dan metode penerjemahan bahasa slang dalam komik Crayoh Shinchan karya Yoshito Usui [Procedures and methods used in translating slangs in 
Crayon Shinchan cartoon written by Yoshito Usui]. (Undergraduate dissertation). Udayana University, Denpasar, Indonesia.

Peterlin, A. P. (2014). Academic discourse in translation: Trainee translators' performance, experience and perception of rhetorical conventions. English for Specific Purposes, 36, 6073.

https://doi.org/10.1016/j.esp.2014.06.0 01

Petrescu, C. (2015). Trainer's Choices in Teaching Translating/Interpreting. Procedia-Social and Behavioral Sciences, 197, 922-929.

Pratama, I. D. (2015). Kreativitas dalam penerjemahan iklan [Creativity in translating advertisement]. Jurnal Probisnis, 8(1), 44-57.

Prieto Ramos, F. (2011). Developing legal translation competence: An integrative process-oriented approach. Comparative LegilinguisticsInternational Journal for Legal Communication, 5, 7-21.

Pym, A. (2014). Exploring translation theories (2nd ed.). London: Routledge.

Richards, J. C. (2001a). Curriculum development in language teaching. Ernst Klett Sprachen.

Richards, J. C. (2001b). Curriculum development in language teaching. https://doi.org/10.1111/j.15404781.2007.00543_2.x

Robinson, D. (2012a). Becoming a translator: An introduction to the theory and practice of translation. Routledge.

Robinson, D. (2012b). Becoming a translator: An introduction to the theory and practice of translation (3rd ed.). London: Routledge.

Rojo, A., Ramos, M., \& Valenzuela, J. (2014). The emotional impact of translation: A heart rate study. Journal of Pragmatics, 71, 31-44. https://doi.org/10.1016/j.pragma.2014. 07.006

Ross, N. J. (2000). Interference and intervention: Using translation in the EFL classroom. Modern English Teacher, 9(3), 61-66.

Schaeffer, M., \& Carl, M. (2014). Measuring the cognitive effort of literal translation processes. Proceedings of the EACL 2014 Workshop on Humans and Computer-Assisted Translation, 29-37.

Schäffner, C., \& Adab, B. (2000). Developing translation competence (Vol. 38). John Benjamins Publishing.

Serpil, H., Durmuşoğlu-Köse, G., Erbek, M., \& Öztürk, Y. (2016). Employing computer-assisted translation tools to achieve terminology standardization in Institutional Translation: Making a case for higher education. Procedia Social and Behavioral Sciences, 231, 76-83.

https://doi.org/10.1016/j.sbspro.2016. 09.074

Setyanta, A. (2013). Loan translation of Sir Authur Conan Doyle's The Memoirs of Sherlock Holmes into Daisy Diana's Memoir Sherlock Holmes (Yogyakarta State University). https://doi.org/10.1017/CBO97811074 15324.004

Shuttleworth, M. (2014). Dictionary of translation studies. Routledge.

Srikandi, C. N. (2010). Borrowing in the translation of D. H. Lawrence's Lady Chatterley's Lover into Indonesian. (Undergraduate dissertation). University of North Sumatra, Medan, Indonesia.

Stepanova, V. V. (2017). Translation strategies of legal texts (EnglishRussian). Procedia - Social and 
Behavioral Sciences, 237, 1329-1336. https://doi.org/10.1016/j.sbspro.2017. 02.218

Suryawinata, Z., \& Hariyanto, S. (2003). Translation: Bahasan teori \& penuntun praktis menerjemah [Translation: Theory and practice of translating]. Yogyakarta: Kanisius.

Venuti, L. (2012). The translation studies reader. Routledge.

Wongranu, P. (2017). Errors in translation made by English major students: A study on types and causes. Kasetsart Journal of Social Sciences, 38(2), 117-122.

https://doi.org/10.1016/j.kjss.2016.11. 003

Yang, X., Li, J., \& Xing, B. (2018). Behavioral patterns of knowledge construction in online cooperative translation activities. The Internet and Higher Education, 36, 13-21. https://doi.org/10.1016/j.iheduc.2017. 08.003

Yousofi, N. (2014). Describing the errors in the translations of Iranian novice
English translators. Procedia - Social and Behavioral Sciences, 98, 19521958.

https://doi.org/10.1016/j.sbspro.2014. 03.628

Yuliasri, I. (2014). Translation techniques and equivalence in the Indonesian translation of humor in Harry Potter and the Sorcerer's Stone. Translating Asia: Then and Now. Bangkok.

Zagot, M. A., \& Vozdvizhensky, V. V. (2014). Translating Video: Obstacles and Challenges. Procedia - Social and Behavioral Sciences, 154, 268-271. https://doi.org/10.1016/j.sbspro.2014. 10.149

Zainudin, I. S., \& Awal, N. M. (2012a). Teaching translation techniques in a university setting: Problems and solutions. Procedia-Social and Behavioral Sciences, 46, 800-804.

Zainudin, I. S., \& Awal, N. M. (2012b). Translation techniques: Problems and solutions. Procedia-Social and Behavioral Sciences, 59, 328-334. 